\title{
Assessment of Microbial Contamination in Products of Animal Origin: Stretched-curd Cheese, Yogurt and Fresh Sausage
}

Denise Maria de Souza Mendes ${ }^{1}$

https://orcid.org/0000-0002-8105-0282

\section{Bruno Vinícius Bastos ${ }^{2}$}

https://orcid.org/0000-0003-2066-2426

Cassia Ribeiro Koki ${ }^{2}$

https://orcid.org/0000-0002-9673-7108

\section{Daniele Bach ${ }^{2}$}

https://orcid.org/0000-0001-9208-4624

Gisele Kirchbaner Contini ${ }^{2}$

https://orcid.org/0000-0003-1369-3515

Lorena Alves de Mattos ${ }^{2}$

https://orcid.org/0000-0002-8905-0949

Mateus Flórido Cubo ${ }^{2}$

https://orcid.org/0000-0003-1916-0306
Priscila Arcoverde Wosiack ${ }^{2}$

https://orcid.org/0000-0001-6594-8538

Rafaela Gomes da Silva ${ }^{2}$

https://orcid.org/0000-0002-5434-2909

Raíssa Arantes Barboza ${ }^{2}$

https://orcid.org/0000-0003-2714-0508

Taynara Pacheco Valério ${ }^{2}$

https://orcid.org/0000-0003-4566-6773

Luiz Gustavo Lacerda ${ }^{1,2}$

https://orcid.org/0000-0002-4689-5431

Luís Antônio Esmerino3

https://orcid.org/0000-0003-2495-3490

Alessandro Nogueira ${ }^{1,2^{*}}$

https://orcid.org/0000-0001-7671-3056

${ }^{1}$ State University of Ponta Grossa, Department of Food Engineering, Ponta Grossa, Paraná, Brazil; ${ }^{2}$ State University of Ponta Grossa, Graduate Program in Food Science and Technology, Ponta Grossa, Paraná, Brazil; ${ }^{3}$ State University of Ponta Grossa, Department of Clinical and Toxicological Analysis, Ponta Grossa, Paraná, Brazil.

Received: 2019.12.17; Accepted: 2020.02.14.

${ }^{*}$ Correspondence: alessandronog@yahoo.com.br; Tel.: +55-42-32203775

\section{HIGHLIGHTS}

- Coliforms at $35^{\circ} \mathrm{C}$ and $45^{\circ} \mathrm{C}$ can suggests the lack of sanitary practices;

- Water in the processing can be a source of contamination and should be monitored;

- S. aureus can be an indicator of the quality in good manufacturing practices during food processing.

Abstract: Animal products are sources of microbiological contamination when the process has hygienicsanitary control fails. Therefore, this work aims the evaluation of the pathogenic microorganisms presented in samples from the Brazil southern region of yogurt $(N=101)$, stretched curd cheese $(N=31)$, fresh sausage $(\mathrm{N}=22)$ and processing water $(\mathrm{N}=63)$. Analyses of coliforms at $45^{\circ} \mathrm{C}$, Staphylococcus aureus, Salmonella sp. and Escherichia coli were performed. Analysis indicated processing water is an important contamination source to be monitored, because the majority of samples presented results above the regulation limits. Thermal treatment and fermentation such as stretched curd cheese and yogurt appeared to be more stable 
against contamination during processing. In this study, for coliforms at $45^{\circ} \mathrm{C}$, only one cheese sample and $12 \%$ of total yogurt samples exceeded the Brazilian legislation limit. None of sausage samples presented any contamination. On the other hand, values found in both processing water and dairy products indicated failures in application and monitoring of good manufactured practices.

Keywords: products of animal origin, Coliforms, Staphylococcus aureus, Salmonella sp. and Escherichia coli.

\section{INTRODUCTION}

In 2017, Brazilian production of animal protein was one of the largest worldwide. Among them, milk and pork with 22.7 and 3.3 million tons, respectively, were the main sources [1, 2]. Products from raw protein are widely and produced and consumed, such as cheese with 755 thousand tons in 2018 [2], yogurt with 840 thousand tons and sausages, including fresh sausages, with 1.5 million tons in 2016 [3].

Recent data shows that a rate of 1 in 10 people gets illness from contaminated food daily while this can be the cause of 420,000 deaths per day [4,5]. Between 2009 and 2018, water was the main source that caused food outbreaks in Brazil (21.1\%). Milk and dairy products were in fourth place with $7.8 \%$ and meat sausages in $14^{\text {th }}$ place with $2 \%$ [6]. According to Fung and coauthors [5], bacteria are the most serious and lethal agents that cause foodborne illness. One of the main microorganisms groups used as contamination indicators are the coliforms [7]. Among the 80 outbreaks identified in the laboratory in 2018, Escherichia coli stands out for being the etiological agent in $27.5 \%$ of cases [6].

Microbiological contaminants can be found from processing water, raw materials and failures during processing, distribution or storage $[8,9]$. Coliforms at $45^{\circ} \mathrm{C}$ are fecal indicators, and $E$. coli is a microorganism indicator of this source of contamination. Total coliforms, $S$. aureus and Salmonella sp. are normally related to poor hygienic and sanitary conditions, inadequate handling and spoiled raw materials [10,11].

Problems found in dairy products, like cheese and yogurt, may originate from high microbial counting. It can be due raw milk, failures and contaminants after heat treatment, contamination in the started culture or curd and poor hygiene in the utensils, equipment and environment used in the production $[12,10,13,14]$. Cheese spoilage also can happens in the brine and curd stages [15]. Contamination in meat sausage products is related to bad raw material quality and good manufacturing failures [16,17].

Pathogenic microorganisms can lead to inflammation in the gastrointestinal tract, complications regarded to several toxic substances production, generalized infections and in some cases, it can leads to death [18] Salmonella sp. is responsible for generalized infections and the major cause of hospitalizations and deaths worldwide $[19,20]$. The symptoms by this contamination are diarrhea, fever, headache and abdominal pain $[21,22]$. Other bacteria found in contaminated food are pathogenic $E$. coli, which leads to diarrhea, urinary tract infections and even meningitis [23]. According to Tranter [24], Staphylococcus aureus causes food poisoning because it produces extracellular toxins, leading to symptoms such as nausea, vomiting, abdominal pain, and diarrhea within 2 to 6 hours after ingestion of contaminated food.

Therefore, due to the importance of pathogenic food control and the constant claims about food safety all over the world, this work aims to evaluate the microbiological food quality in animal products (stretchedcurd cheese, yogurt, and fresh sausage), from Brazil Southern region.

\section{MATERIAL AND METHODS}

\section{Material}

Samples of yogurt $(n=101)$, stretched-curd cheese $(n=31)$, fresh sausage $(n=22)$ and water applied in the processing $(n=63)$ were supplied by companies located in the southern region of Brazil. Defective samples on the package or expired date have been discarded. All reagents used in this study were of analytical grade.

\section{Methods}

In the yogurt samples, coliform analysis was performed at $45^{\circ} \mathrm{C}$. Analysis of Coliforms, Staphylococcus sp. and Salmonella sp. were performed in the samples of stretched-curd cheese and fresh sausage. The analysis of coliforms, aerobic mesophylls and E. coli were performed in the water samples. 


\section{Preparation of samples}

For the food analyses, $25 \mathrm{~g}$ or $\mathrm{mL}$ of the samples were crushed and homogenized in $225 \mathrm{~mL}$ of $0.1 \%$ sterile peptone water (HiMedia Laboratories, Mumbai, India) previously sterilized in an autoclave at $121^{\circ} \mathrm{C}$ for $15 \mathrm{~min}$. From this dilution $10^{-1}$ the serial dilutions were performed up to $10^{-4}$. For water analysis, there was no need for prior dilution.

\section{Salmonella sp. analysis}

Salmonella sp. is a qualitative analysis, performed according to ABNT NBR ISO 6579/2007 [25], and the result is given as positive or negative in $25 \mathrm{~g}$ of the sample. The sample was diluted to $10^{-1}$ in buffered peptone distilled water (ADPT) 1\% (HiMedia Laboratories, Mumbai, India), incubated at room temperature between 4 and 6 hours and then at $35{ }^{\circ} \mathrm{C}$ for 24 hours. $1 \mathrm{~mL}$ of ADPT culture was transferred aseptically in tubes with tetrationate, $0.15 \mathrm{~mL}$ of brilliant green solution and $0.2 \mathrm{~mL}$ of iodinated iodine solution and in tubes with selenite medium. The tubes were incubated at $41^{\circ} \mathrm{O}$ for 24 and 48 hours. After incubation, they were plated in Salmonella-Shigella (SS) medium (HiMedia Laboratories, Mumbai, India) and brilliant green agar $(B G)$ at $35 \stackrel{\circ}{\circ}$ for 24 hours. After the incubation period, the presence of colonies and their characteristics were verified. Colonies in the SS medium that were yellow, transparent, small, with or without black spots were plated in the modified Rugai medium and identified biochemically [26]. The same procedure was performed for colonies that presented small size, pink and transparent coloration at BG medium. Colonies were also submitted to agglutination reaction using Salmonella polyvalent antisera (Probac, São Paulo, Brazil) [26].

\section{Staphylococcus aureus analysis}

$S$. aureus were determined to cheese and sausage products [26]. The plate counting method was performed from sample preparation, inoculum incubation and counting from presumptive colonies. $S$. aureus strains were identified by confirmatory tests. From the typical colonies confirmation tests presented by Silva [27], three were applied: (a) catalase test, (b) coagulase test and (c) termonuclease test. Among these, test (b) was modified, replacing rabbit EDTA plasma with rabbit saline plasma $(0.1 \%)$.

\section{Coliforms analysis}

Coliforms count at $35^{\circ} \mathrm{C}$ and $45^{\circ} \mathrm{C}$ were performed by the most probable number method (MPN). $10 \mathrm{ml}$ of the sample were inoculated in inverted Durhan tubes with concentrated Laurel Sulfate Triptose (LST) broth (UroGen, New York, USA). Tubes were incubated at $35^{\circ} \mathrm{C}$ for 48 hours. From each positive tube, in the presence of gas, an aliquot was taken and inoculated in inverted Durhan tubes with brilliant green $2 \%$ bile broth (VB) (Kasvi, Sao Jose dos Pinhais, Brazil). These tubes were incubated at the same conditions described. The same procedure were applied for Escherichia coli (EC) broth (Kasvi, Sao Jose dos Pinhais, Brazil) where tubes were incubated at $45^{\circ} \mathrm{C}$ for 24 hours in a water bath. The number of positives tubes were analyzed according to MPN chart and expressed as described by APHA [28]. From each tube with EC broth, a sample was plated in Teague or BEM. The plates were incubated at $35^{\circ} \mathrm{C}$ for 24 hours. After the incubation, the typical colonies were identified and then inoculated in modified Rugai tubes at $35{ }^{\circ} \mathrm{C}$ for 24 hours and identified biochemically [26]. The results were analyzed on a proper table.

\section{Aerobic mesophilic analysis}

Aerobic mesophilic bacteria analysis was performed using the leakage plate method. In sterile Petri dishes, $0.4 \mathrm{~mL}$ triphenyltetrazolium chloride (TTC) (Vetec Quimica, Rio de Janeiro, Brazil) and $1 \mathrm{ml}$ diluted sample were transferred. The plate counting agar (APC) at $45^{\circ} \mathrm{C}$ (Kasvi, São José dos Pinhais, Brazil) was added to the plate and carefully homogenized by slow rotational movements. The plates were incubated at $35 \pm 1{ }^{\circ} \mathrm{C}$ for 48 hours. After this period, the colonies were counted (multiplied by dilution) and the results obtained were expressed in CFU/g or $\mathrm{mL}$. Colonies between 30 and 300 were considered significant.

\section{RESULTS}

Water samples were not conformed to Brazilian regulations regarding the absence of coliforms in 100 $\mathrm{mL}[29,30]$. Presence of thermal tolerant bacteria were found in all the samples at $35{ }^{\circ} \mathrm{C}$ and in $97 \%$ of samples at $45^{\circ} \mathrm{C}$ (Table 1$)$. 
Table 1. Microbiological assessment of water samples ( $\mathrm{N}=63)$ applied into food processing. Coliforms at $35^{\circ} \mathrm{C}(\mathrm{NMP} / \mathrm{g})^{*} \quad$ Coliforms at $45^{\circ} \mathrm{C}(\mathrm{NMP} / \mathrm{g})^{\star *}$

$<1.1(49)$
$6.9(3)$
$9.2(3)$
$12(2)$
$16(1)$
$23(5)$

Absent (2)
$<1.1(53)$
$6.9(3)$
$9.2(1)$
$12.1(2)$
$16(1)$
$>23(1)$
-
-
Aerobic Plate Count $(\mathrm{UFC} / \mathrm{mL})^{* * *}$

$50(1)$
$<10^{2}(8)$
$<2.2 \times 10^{2}(2)$
$5.4 \times 10^{2}(1)$
$1.0 \times 10^{3}(1)$
$2.9 \times 10^{3}(1)$
$6.3 \times 10^{3}(2)$
$9.3 \times 10^{3}(1)$
$2.3 \times 10^{4}(1)$
nd $(45)$

Note: Values in parentheses refer to number of samples analyzed. ${ }^{*}$ Limit value for Coliforms at $35{ }^{\circ} \mathrm{C}$ : absence/100 $\mathrm{mL}$; ${ }^{* *}$ limit value for coliforms at $45^{\circ} \mathrm{C}$ : absence $/ 100 \mathrm{~mL}$; ${ }^{* * *}$ limit value for Aerobic Plate Count: $5 \times 10^{2} \mathrm{UFC} / \mathrm{mL}$. nd: not determined.

Table 2 shows only one sample of cheese within the legislation limits for coliforms at $45^{\circ} \mathrm{C}\left(5 \times 10^{3}\right.$ $\mathrm{NMP} / \mathrm{g})$.

Table 2. Microbiological assessment of stretched curd cheese $(N=26)$, fresh sausage $(N=22)$ and yoghurt $(N=101)$.

\begin{tabular}{|c|c|c|c|}
\hline Microbiological limits & Stretched curd cheese & Fresh sausage & Yoghurt \\
\hline & $<3(18)$ & $<3(11)$ & $<3(72)$ \\
\hline & $4(2)$ & $4(3)$ & $4(10)$ \\
\hline & $11(1)$ & $9(3)$ & $9(6)$ \\
\hline \multirow[t]{6}{*}{ Coliforms at $45^{\circ} \mathrm{C}(\mathrm{NMP} / \mathrm{g})^{*}$} & $43(3)$ & $15(1)$ & $23(4)$ \\
\hline & $240(1)$ & $23(2)$ & $43(3)$ \\
\hline & $>1100(1)$ & $460(1)$ & $75(2)$ \\
\hline & - & $1100(1)$ & $93(1)$ \\
\hline & - & - & $150(1)$ \\
\hline & - & - & $240(1)$ \\
\hline \multirow[t]{2}{*}{ Staphylococcus aureus (UFC/g) $)^{\star *}$} & $<10^{2}(24)$ & $<10^{2}(22)$ & - \\
\hline & nd (2) & & - \\
\hline Salmonella sp*** & $\begin{array}{l}\text { Absent (24) } \\
\text { nd (2) }\end{array}$ & $\begin{array}{l}\text { Absent (21) } \\
\text { nd (1) }\end{array}$ & $\begin{array}{l}- \\
-\end{array}$ \\
\hline
\end{tabular}

Note: Values in parentheses refer to number of samples analyzed. ${ }^{*}$ Limit value for Coliforms at $45{ }^{\circ} \mathrm{C}: 10^{3} \mathrm{NMP} / \mathrm{g}$; ** limit value for Staphylococcus aureus: $<10^{3} \mathrm{UFC} / \mathrm{g}$; ${ }^{* \star *}$ limit value for Salmonella: absence in $25 \mathrm{~g}$. nd: not determined.

Sausage samples (Table 2) were within the Brazilian legislation established limits for Staphylococcus aureus (5 $\left.\times 10^{2} \mathrm{UFC} / \mathrm{g}\right)$.

\section{DISCUSSION}

According to Alves and coauthors [31], water contaminations can occur due to failures in the public collection system, also because of the bad hygiene and maintenance of the water reservoir. In countryside area there is a lack of treatment and protection of artesian wells, streams, rivers and dams [32]. As well as to the Brazilian regulations, the samples were not conformed in the United States legislation, which states that total coliforms should not surpass the limit of $5 \%$ from total samples analyzed in a month [33]. Aerobic Plate Count presented $9.5 \%$ of results above the established limit $\left(5 \times 10^{2} \mathrm{UFC} / \mathrm{mL}\right)$, being $10^{4} \mathrm{UFC} / \mathrm{mL}$ the highest value found. Ćirić and coauthors [34] claim that recontamination can occur after water treatment and chlorination. Aerobic Mesophilic Bacteria can recover from chemical effects and lack of nutrients, being able to proliferate in treated water distributed.

All the samples of stretched curd cheese, fresh sausage and yoghurt were according the Brazilian legislation limits for Staphylococcus aureus (max. $10^{3} \mathrm{UFC} / \mathrm{g}$ ) and Salmonella spp. (absence) [35]. The European Union limits for coliforms count in cheese is ten times lower than Brazilian limits (100 UFC/g) [36]. Prates and coauthors [37] and Marinheiro and coauthors [38] also found absence of Salmonella spp in stretched curd cheeses. It can be related to thermal process since the curd $(5.2 \mathrm{pH})$ is stretched under water at high temperature $\left(55-88^{\circ} \mathrm{C}\right)$ and can reach 40 to $70^{\circ} \mathrm{C}$ during 5 to 10 minutes [39].

Sausage samples analyzed had results similar to studies from Daguer and coauthors [40] where Staphylococcus aureus contamination was not found (max $5 \times 10^{2} \mathrm{UFC} / \mathrm{g}$ ) among meat samples obtained from Paraná state. These results are due adequate control and sanitary processes [35] during prepare of meat products. Only one sample was found near the maximum limit allowed $\left(5 \times 10^{3} \mathrm{NMP} / \mathrm{g}\right)$ for coliforms at 
$45^{\circ} \mathrm{C}$ (Table 2). The EU establishes a $500 \mathrm{UFC/g}$ limit for E. coli. Coagulase-positive staphylococcal (max. $5 \times 10^{3} \mathrm{UFC} / \mathrm{g}$ ) and Salmonella sp. (absent in $25 \mathrm{~g}$ ) were not detected among contamination [33, 41]. However, Salmonella sp was found in other studies in the percentage of $28.3 \%$ [42], 24.4\% [43] and $17.1 \%$ [44] of samples analyzed. Fresh pork products usually do not go under thermal or fermentative processing hence the microbiological quality of raw material it is a critical control point $[45,46]$.

Within the yogurt samples, $12 \%$ presented higher values than the established limits in the legislation for coliforms at $45^{\circ} \mathrm{C}$. The current Brazilian legislation regulates a maximum of $10 \mathrm{MPN} / \mathrm{g}$ [47], as well the EUA and EU are $10 \mathrm{UFC} / 100 \mathrm{~g}$ to coliforms and $10 \mathrm{UFC} / \mathrm{mL}$ to enterobacteria, respectively $[48,36]$. Fermentation process that occurs in yogurt promotes the medium acidification, which can inhibit contamination by microorganisms as coliforms [13]. According to Emiliano and coauthors [49], presence of coliforms is an unsatisfactory quality indicator of hygiene practices during processing and packing. National and international regulations establish good manufacturing practices for food services and home cooking, in order to ensure consumers health safety as well food quality [50,51]. These practices are essential in order to avoid food contamination. Therefore, microbiological analysis are fundamental for food safety assurance and for each food category there are specific and mandatory analyses [52].

\section{CONCLUSION}

Coliforms at $35{ }^{\circ} \mathrm{C}$ and $45^{\circ} \mathrm{C}$ results suggests that are a lack of sanitary practices at some point of the processes analyzed. It can occur because failures in important process stages, inadequate food manipulation by employees and bad water quality. Contamination by mesophilic aerobic bacteria found in processing water samples confirmed this. Improvements in good manufacturing practices are necessary as well supervision and controlling of these processes in order to ensure the efficiency and food safety. To coliforms at $45^{\circ} \mathrm{C}$, all fresh sausage samples reached the limits established by the legislation. Only one cheese sample and $12 \%$ of yogurt samples were above the regulations limits allowed. All fresh sausage and cheese samples were within the parameters established for $S$. aureus and Salmonella sp. Through $S$. aureus results it can be noticed the quality in good manufacturing practices during food processing (stretched-curd cheese and fresh sausage) manufactured by industries from South Brazil in the samples evaluated in this work.

Acknowledgments: The authors would like to acknowledge all staff from CTA-UEPG for providing the facilities for analysis. This study was financed, in part, by the Coordenação de Aperfeiçoamento de Pessoal de Nível Superior Brasil (CAPES) - Finance Code 001. A. Nogueira acknowledge the support of the National Council for Scientific and Technological Development (CNPq) (Grant \#303789/2016-6).

Conflicts of Interest: The authors declare no conflict of interest.

\section{REFERENCES}

1. Brisola MC, Crecencio RB, Bitner DS, Frigo A, Rampazzo L, Stefani LM, et al. Escherichia coli used as a biomarker of antimicrobial resistance in pig farms of Southern Brazil. Sci Total Envirobn. 2019;647:362-8.

2. United States. United States Department of Agriculture. Dairy: World Markets and Trade. 2019.

3. Brazil. Instituto Brasileiro de Geografia e Estatística. Produção e vendas dos produtos e/ou serviços industriais, segundo as classes de atividades e os produtos. 2016.

4. Food and Agriculture Organization of the United Nations. FAO. The future of food safety. There is no food security without food safety. 2019.

5. Fung F, Wang H, Menon S. Food safety in the 21st century. Biomed J. 2018;41(2):88-95.

6. Brazil. Ministério da Saúde. Surtos de Doenças Transmitidas por Alimentos no Brasil. Diário Oficial da República Federativa do Brasil. 2016.

7. Lues JFR, Van Tonder I. The occurrence of indicator bacteria on hands and aprons of food handlers in the delicatessen sections of a retail group. Food control. 2007;18(4):326-32.

8. Food and Agriculture Organization of the United Nations. FAO. Protect the quality and safety of your food: The Importance of Food Safety. 2019.

9. Meschede MSC, Figueiredo BR, Alves RIS, Segura-Muñoz SI. Drinking water quality in schools of the Santarém region, Amazon, Brazil, and health implications for school children. Rev. Ambient. Água. 2018;13(6):1-19.

10. Vasek OM, Mazza SM, Giori GS. Physicochemical and microbiological evaluation of corrientes artisanal cheese during ripening. Food sci technol. 2013;33(1):151-60.

11. Nicolau ES, Mesquita AJ, Borges GT, Kuaye AY. Staphylococcus aureus no processamento de queijo mussarela: detecção e avaliação da provável origem das linhagens isoladas. Hig Aliment. 2004;18(125):51-6.

12. Belli P, Cantafora AFA, Stella S, Barbieri S, Crimella C. Microbiological survey of milk and dairy products from a small scale dairy processing unit in Maroua (Cameroon). Food Control. 2013;32(2):366-70.

13. Rodrigues LA, Ortolani MBT, Nero LA. Microbiological quality of yoghurt commercialized in Viçosa, Minas Gerais, Brazil. Afr J of Microbiol Res. 2010;4(3):210-3. 
14. Buzi KA, Pinto JPAN, Ramos PRR, Biondi GF. Microbiological analysis and electrophoretic characterization of mozzarella cheese made from buffalo milk. Ciênc. Tecnol. Aliment. 2009;29:7-11.

15. Kousta M, Mataragas M, Skandamis $P$, Drosinos EH. Prevalence and sources of cheese contamination with pathogens at farm and processing levels. Food Control. 2010;21(6):805-15.

16. Mohammed AM. Sulieman AME, Salih ZA, Mahgoud A. Quality Characteristics of Laboratory-Made Mortadella Meat Product. International Journal of Food Science and Nutrition Engineering. 2015;5(2):96-100.

17. Dias FS, Ramos CL, Schwan RF. Characterization of spoilage bacteria in pork sausage by PCR-DGGE analysis. Food Sci. Technol. 2013;33(3):468-74.

18. Rangel JM., Sparling PH., Crowe C., Griffin, PM., Swerdlow DL. Epidemiology of Escherichia coli O157: H7 outbreaks, united states, 1982-2002. Emerg. infect. dis. 2005; 11(4): 603.

19. Forsythe, SJ. Microbiologia da segurança alimentar. São Paulo: Artmed, 2002.

20. Scallan E, Hoekstra RM, Mahon BE, Jones TF, Griffin PM. An assessment of the human health impact of seven leading foodborne pathogens in the United States using disability adjusted life years. Epidemiol Infect. 2015;143(13):2795-2804.

21. Farré MRS, Sánchez DO, Varela CA, Sanahuja MS, Recasens AR, Jové JP. Aspectos epidemiológicos y carga asistencial de gastroenteritis agudas por Campylobacter y Salmonella. Med clin. 2015;145(7):294-7.

22. Chávez de la Peña M, Higuera-Iglesias AL, Huertas-Jiménez MA, Báez-Martínez R, Morales-de León J, ArteagaCabello $F$, et al. Brote por Salmonella enteritidis en trabajadores de un hospital. Salud pública de Méx. 2001;43(3):211-6.

23. Aijuka M, Buys EM. Persistence of foodborne diarrheagenic Escherichia coli in the agricultural and food production environment: Implications for food safety and public health. Food Microbiol. 2019;82:363-70.

24. Tranter HS. Foodborne staphylococcal illness. Lancet (British edition). 1990;336(8722):1044-6.

25. Associação Brasileira de Normas Técnicas. ABNT. NBR ISO 6579:2002. Microbiology of food and animal feeding stuffs - Horizontal method for the detection of Salmonella spp. 2014.

26. Silva, N D, Junqueira, V C \& Silveira, N. F.Manual de métodos de análise microbiológica de alimentos. Varela. 2001.

27. Silva N, Junqueira VCA, Silveira NFA. Manual de métodos de análise microbiológica de alimentos e água. In: Manual de métodos de análise microbiológica de alimentos e água. 2010:155-8.

28. American Public Health of Water and Wastewater. Standard Methods for the Examination of Water and Wastewater. 16th ed. Washington: American Public Health Association;1985.

29. Brazil. Ministério da Saúde. Aprova o Regulamento do Controle e da Vigilância da Qualidade da Água para Consumo Humano e seu Padrão de Potabilidade (Portaria de Consolidação PRC n 5, de 28 de Setembro de 2017). Diário Oficial da República Federativa do Brasil.2017.

30. European Commission. Commission directive (EU) 2015/1787 of 6 October 2015 amending Annexes II and III to Council Directive 98/83/EC on the quality of water intended for human consumption. Off. J. Eur. Union. 2015:6-17.

31. Alves SGS, Ataide CDG, Silva JX. Análise Microbiológica de coliformes totais e termotolerantes em água de bebedouros de um parque público de Brasília, Distrito Federal. Rev. Cient. Sena Aires. 2018;7(1):12-7.

32. Ramos STB, Mafra MSH, Rech TD, Siegloch AE, Rech AF. Water quality of springs in areas under different land uses in the southern highlands of Santa Catarina. Rev. Ambient. Água. 2018;13(4):1-10.

33. United States. United States Environmental Protection Agency. National primary drinking water regulations. 2009.

34. Ćiric S, Ilic Z, Miloseic B, Spasic Z, Stojković J. Use of the direct and cultivation methods in the bacteriological examination of water in water supply system. Biotech Anim Husbandry. 2011;27(3):1337-43.

35. Brazil. Agência Nacional de Vigilância Sanitária. Aprova o Regulamento técnico sobre padrões microbiológicos para alimentos (Resolução RDC no 12, de 2 de Janeiro de 2001). Diário Oficial da República Federativa do Brasil. 2001.

36. European Commission. Commission Regulation (EC) No 2073/2005 of 15 November 2005 on microbiological criteria for foodstuffs. Off. J. Eur. Union. 2005;50:1-16.

37. Prates DDF, Würfel SR, Goldbeck JC, Lima ASD, Lopes GV, Silva WPD. Microbiological quality and safety assessment in the production of moderate and high humidity cheeses. Ciênc Rural. 2017;47(11).

38. Marinheiro MF, Ghizzi LG, Cereser ND, De Lima HG, Timm CD. Microbiological quality of sliced and block mozzarella cheese. Semina: ciênc agrar. 2015;36 (3):1329-34.

39. McSweeney PLH, Fox P F, Cotter PD, Everett DW. Cheese Chemistry, Physics and Microbiology. $4^{\text {th }}$ ed. Academic Press; 2017.

40. Daguer H, Silva HD, Higashiyama ET, Zanette C M, Bersot LS. Quality Evaluation of Meat Products Produced Under Federal Inspection in the State of Paraná. Braz. Animal Sci. 2011;12(2):359-64.

41. European Union. Commission Regulation - EC. The commissions of the European communities, Commission Regulation (EC) $n^{\circ}$ 1441/2007 of 5 December 2007 amending Commission Regulation (EC) $n^{\circ}$ 2073/2005 on microbiological criteria for foodstuffs. Official Journal of the European Union, L322, 2007.

42. Cavalin PBB, Sarmiento JJP, Kobayashi RKT, Nakazato G, Ocaña AN, Oliveira TCRM. Detection of Salmonella spp. and diarrheagenic Escherichia coli in fresh pork sausages. Semina: ciênc agrar. 2018; 39(4):1533-46.

43. Mürmann L, dos Santos MC, Cardoso M. Prevalence, genetic characterization and antimicrobial resistance of Salmonella isolated from fresh pork sausages in Porto Alegre, Brazil. Food Control. 2009; 20(3):91-195. 
44. Trimoulinard A, Beral M, Henry I, Atiana L, Porphyre V, Tessier C. et al. Contamination by Salmonella spp., Campylobacter spp. and Listeria spp. of most popular chicken-and pork-sausages sold in Reunion Island. Int $\mathrm{j}$ food microbiol. 2017:250:68-74.

45. Roca M, Incze K. Fermented sausages. Food Rev Int. 1990;6(1):91-118.

46. Castagna SMF, Schwarz P, Canal CW, Cardoso MRI. Prevalência de suínos portadores de Salmonella sp. ao abate e contaminação de embutidos tipo frescal. Acta Sci Vet. 2004; 32(2):141-7.

47. Brazil. Ministério da Agricultura. Instrução normativa oํ 46, de 23/10/2007. Diário Oficial da República Federativa do Brasil. 2007.

48. United States. United States Department of Agriculture. USDA Specifications for Yogurt, Nonfat Yogurt and Low fat Yogurt. 2001.

49. Emiliano JVS, Junior SM, Martins FO, Silva CR, Campos RCAB, Balbi PVT, Martins ADO. Avaliação físico-química e microbiológica de iogurtes comercializados em Rio Pomba/MG e comparação com os parâmetros da legislação. Vértices. 2017; 19(1):191-200.

50. Brazil. Agência Nacional de Vigilância Sanitária. Aprova o Regulamento técnico de boas práticas para serviço de alimentação (Resolução no 216, de 15 de setembro de 2004). Diário Oficial da República Federativa do Brasil. 2004.

51. Food and Agriculture Organization of the United Nations (FAO) and the World Health Organization (WHO). Codex Alimentarius. Food Hygiene basic texts. Fourth Edition. 2009.

52. Brazil. Ministério da Agricultura, Pecuária e Abastecimento. Aprova o Regulamento técnico sobre as condições higiênico-sanitárias e de boas práticas de fabricação para estabelecimentos elaboradores/industrializadores de alimentos (Portaria no 368, de 04 de setembro de 1997). Diário Oficial da República Federativa do Brasil. 1997.

(c) 2020 by the authors. Submitted for possible open access publication under the terms and conditions of the Creative Commons Attribution (CC BY NC) license (https://creativecommons.org/licenses/by-nc/4.0/). 